\title{
Study on Photo-catalytic Degradation of Odor Compound in FreshWater
}

\author{
Xilei Zhao \\ Dept. of Environmental and Biological Engineering, \\ Nanjing University of Science and Technology, \\ Nanjing, China \\ peggyzhao0704@hotmail.com
}

\author{
Zhengping Wang* \\ Dept. of Environmental and Biological Engineering, \\ Nanjing University of Science and Technology, \\ Nanjing, China \\ wzp306@sina.com
}

\begin{abstract}
The odor episode events caused by the odor compounds in water have profoundly influenced the ways people live and work, whereas there are few effective approaches to tackle this problem. In this paper, $\beta$-Ionone was taken as object to study the basic law of its photo-catalytic degradation with nanometer Titanium dioxide. The optimal initial concentrations of odor compound, dosage of the photo-catalyst and $\mathrm{pH}$ in water have been deeply discussed. The results indicate that the photo-catalytic degradation kinetics of $\beta$-Ionone follows the pseudo first-order reaction.
\end{abstract}

Keywords- $-\beta$-Ionone; Photo-catalytic Degradation; $\mathrm{TiO}_{2}$

\section{INTRODUCTION}

Recently, odor emission bursts out frequently due to the increasing eutrophication of water. However, despite not being a direct cause of disease, long-term exposure to such odorants can have a negative side-effect on human beings[1]. Generally, the odorants in water can bedivided into human factors and natural factors. Some odor emissions from agriculture, industry and domestic sewage with inefficient treatment are regarded as human factors[2], whilethose release from algal cells, plankton and actinomycetes[3] as well as metabolic products of microorganisms are the natural factors $[4,5]$.

In China, the technology of odor removal is just at the beginning stage.Chemical oxidation, physical treatment and biological technologies are mainly treatment for odor removal[6]. $\mathrm{TiO}_{2}$ photo-catalysis has been investigated because of its attractive properties in waste water purification as well as renewal energy[7].Owing to its nontoxicity, oxidizing power, low costs and relatively larger band gap

*Corresponding Author: 86-25-84315521

Email:wzp306@sina.com energy $(3.2 \mathrm{eV}), \mathrm{TiO}_{2}$ has been a broadly studied field in last decades[7-10]. Particularly, $\mathrm{TiO}_{2}$ presents a precious property which is unselective during the oxidation reactions[11]. Much particular interest has been devoted to the optimal conditions of experimental parameters which are catalyst loading, light intensity, initial concentration of substrates, initial $\mathrm{pH}$, temperature and mineral salt etc. $[12,13]$.

In previous investigation, industrial wastewater has been mainly addressed the photo-catalytic degradation owing to the stringent regulation on it $[14,15]$. However, photo-catalytic degradation of odor compounds in drinking water is not totally studied. According to the study of monthly report, this paper was mainly focused on the optimal condition in the photo-catalytic degradation of $\beta$-Iononeand exploring the degradation kinetics of $\beta$-Ionone in $\mathrm{TiO}_{2}$ suspension.

\section{EXPERIMENTAL}

\section{Material}

Sodium Hydroxide and Sulfuric Acid were purchased from Nanjing Chemical Reagent Co., Ltd. (analytical grade). $\beta$-Ionone $(>97 \%)$ was obtained from Sigma-Aldrich Co., Ltd. Degussa P25(mostly anatase, purity $>95 \%$ ) catalyst provided by Degussa Company.

\section{Apparatus and Analyses}

Photo reactor: All reactions were performed in a home-made batch reactor. The reactor wasa $2.5 \mathrm{~L}$ glass vessel with three necks at the top used to monitoring $\mathrm{pH}$, adding the lamp and sampling. The $18 \mathrm{~W} / \mathrm{cm}^{2}$ lamp (primary radiation is emitted at $365 \mathrm{~nm}$ ) was placed about $5 \mathrm{~cm}$ underneath the bottom of glass vessel.

Degradation: Appropriate quantity of the $\mathrm{TiO}_{2}$ was suspended in $2 \mathrm{~L}$ of $\beta$-Ionone solution by stirring magnetically and staying for 4hin dark for adsorption equilibrium. The 
initial $\mathrm{pH}$ was adjusted by using a sulfate acid or $\mathrm{NaOH}$ solution.The reaction started by turning on the lamp. $10 \mathrm{~mL}$ of the samples were withdrawn and filtered by $0.45 \mu \mathrm{m}$ membrane to separate the catalyst.

Analysis:Disappearance of $\beta$-Iononeis measured by a UV Detector(Cary 100, Varian) with the absorbance at $305 \mathrm{~nm}$.

\section{III.RESULTS AND DISCUSSION}

\section{Photodegradability of $\beta$-Ionone}

Initially the control of experiments were carried out under the following conditions: (a)self-photolysis of $\beta$-Ionone with UV; (b)under UV with $\mathrm{TiO}_{2}$ and (c) $\beta$-Ionone with catalyst in dark. The results are shown in Figure 1. After 150 min of magnetic stirring without UV irradiation, about $5 \%$ disappeared owing to the adsorption of $\beta$-Ionone on the surface of $\mathrm{TiO}_{2}$. The degradation in UV and UV with $\mathrm{TiO}_{2}$ were about $94 \%$ and $80 \%$ respectively. Figure 2 indicates the changes in the optical conditions under different times.

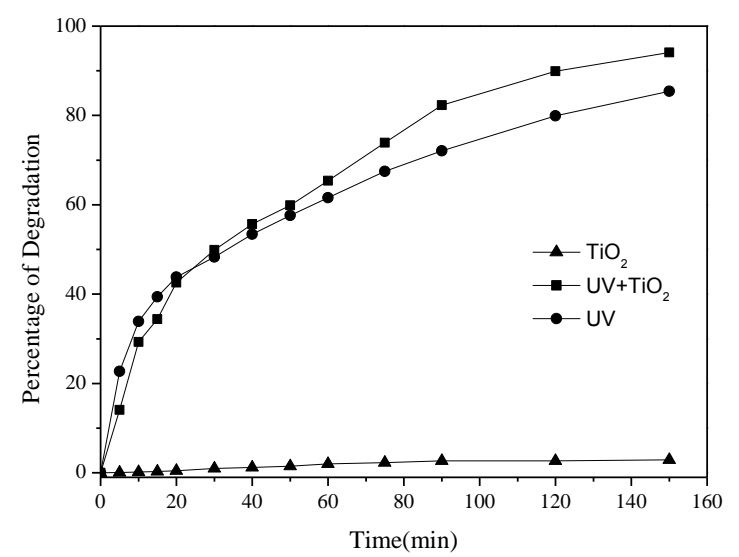

Fig.1Photodegradability of $\beta$-Ionone. $\mathrm{TiO}_{2}=80 \mathrm{mg} / \mathrm{L}$,

$[\beta$-Ionone $]=8 \mathrm{mg} / \mathrm{L}, \mathrm{pH}=2$.

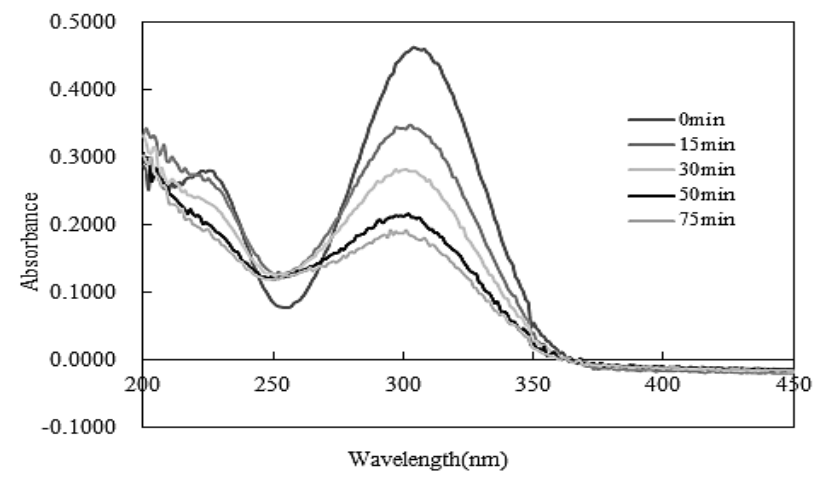

Fig. 2 Typical UV spectrum profiles the degradation of $\beta$-Ionone on P25 catalyst.

\section{Effect of Catalyst Loading}

The degradation efficiency rises with the increasing concentration of $\mathrm{TiO}_{2}$ and approaching to a limiting value at high concentration[16]. However, it is essential to find the optimal amount of $\mathrm{TiO}_{2}$ to get efficient degradation. Figure 3 suggests the effect of $\mathrm{TiO}_{2}$ loading on the degradation efficiency. As the concentration of catalyst added from 0 to $100 \mathrm{mg} / \mathrm{L}$ the degradation efficiency increased from $85 \%$ to $90 \%$, reaching the peak at $92 \%$ with $80 \mathrm{mg} / \mathrm{L}$ of P25.

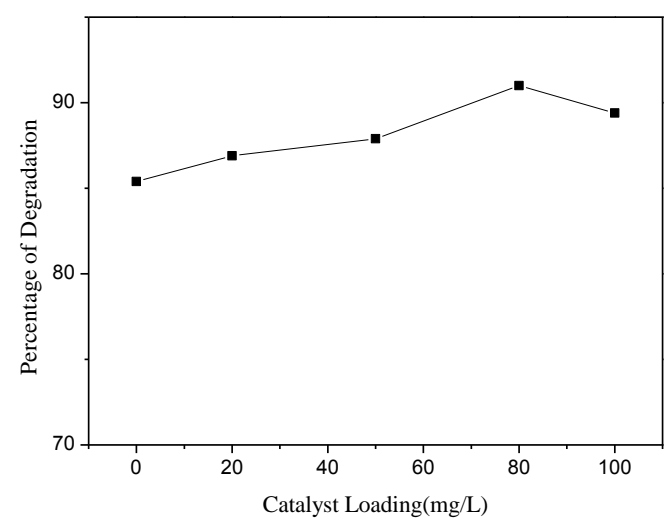

Fig.3 Effect of Catalyst Loading on the degradation efficiency

\section{Effect of Initial Concentration of $\beta$-Ionone}

The effect of various initial concentrations on the degradation was investigated ranging from 5 to $10 \mathrm{mg} / \mathrm{L}$. The results are shown in Table I. It can beseen that with theincreasingof $\beta$-Ionone concentration, the degradation efficiency and removal rate increased as well. After the peak $(8 \mathrm{mg} / \mathrm{L})$, the removal rate and efficiency decreased with the increase in concentration of $\beta$-Ionone. That higher pollutant concentration may impede the photon entering into the solution, which also reduces the catalytic efficiency[17].

TABLEI. Effect of initial concentration of $\beta$-Ionone, $\mathrm{TiO}_{2}=80 \mathrm{mg} / \mathrm{L}, \mathrm{pH}=2$

\begin{tabular}{|c|c|c|c|c|}
\hline $\begin{array}{c}\text { Initial Concentration of } \\
\boldsymbol{\beta} \text {-Ionone/mg. } \mathbf{L}^{-\mathbf{1}}\end{array}$ & $\mathbf{5}$ & $\mathbf{7}$ & $\mathbf{8}$ & $\mathbf{1 0}$ \\
\hline Removal Rate/10-2 $\mathbf{m i n}^{-1}$ & 1.54 & 1.44 & 1.80 & 1.64 \\
\hline Degradation Efficiency & $88.6 \%$ & $89.3 \%$ & $94.1 \%$ & $91.0 \%$ \\
\hline
\end{tabular}

\section{Effect of Initial $\mathrm{pH}$}

The effect of different initial $\mathrm{pH}$ value of $\beta$-Ionone on the efficiency and removal rate has been shown in Table II. By increasing the $\mathrm{pH}$ from acidic to alkaline resulted in 
significant reduction in degradation efficiency and removal rate, from $92.4 \%(\mathrm{pH}=2)$ to $74.8 \%(\mathrm{pH}=12)$ and from $0.0245 \mathrm{~min}^{-1}(\mathrm{pH}=2)$ to $0.0108 \mathrm{~min}^{-1}(\mathrm{pH}=12)$, respectively. Previous studies showswhen $\mathrm{pH}>6.8, \mathrm{TiO}_{2}$ surface becomes negative and repulsive to the negatively charged $\beta$-Ionone. Lower of the $\mathrm{pH}$ motivates the $\mathrm{TiO}_{2}$ particles to aggregate and reduce the adsorption on the $\mathrm{TiO}_{2}$ surface[18].

TABLEII. Effect of initial $\mathrm{pH}$ of $\beta$-Ionone on the efficiency and removal rate with different time

\begin{tabular}{|c|c|c|c|c|c|}
\hline Reaction Time/min & $\mathbf{p H}=2$ & $\mathbf{p H}=5$ & $\mathbf{p H}=7$ & $\mathbf{p H}=9$ & $\mathrm{pH}=12$ \\
\hline 0 & $0.0 \%$ & $0.0 \%$ & $0.0 \%$ & $0.0 \%$ & $0.0 \%$ \\
\hline 30 & $74.5 \%$ & $61.0 \%$ & $49.9 \%$ & $28.1 \%$ & $27.2 \%$ \\
\hline 60 & $85.9 \%$ & $77.7 \%$ & $65.4 \%$ & $48.5 \%$ & $45.8 \%$ \\
\hline 90 & $89.5 \%$ & $84.9 \%$ & $82.3 \%$ & $66.1 \%$ & $61.3 \%$ \\
\hline 150 & $92.4 \%$ & $92.8 \%$ & $94.1 \%$ & $81.9 \%$ & $74.8 \%$ \\
\hline Removal Rate/min ${ }^{-1}$ & 0.0245 & 0.0170 & 0.0180 & 0.0119 & 0.0108 \\
\hline
\end{tabular}

\section{Degradation Kinetics of $\beta$-Ionone}

In this study, a series of experiment was carried out. When $\mathrm{pH}=2$, initial concentration of catalyst was $80 \mathrm{mg} / \mathrm{L}$, the degradation kinetics of $\beta$-Iononewas obtained:

$$
\operatorname{Ln}\left(\mathrm{C}_{0} / \mathrm{C}_{\mathrm{t}}\right)=0.018 \mathrm{t}+.0894
$$

theequationindicates the kinetics follows thepseudo first-order reaction. And $t_{1 / 2}=38.51 \mathrm{~min}, \mathrm{R}^{2}=0.9924$.

\section{IV.CONCLUSION}

In this study, a meaningful kinetic expression for the degradation of $\beta$-Iononewas obtained. The equation is reliable because it was obtained under a variety of different experiment conditions. It can be found that the degradation rate of $\beta$-Ionone isapproximately pseudo first-order because of its concentration optimized. The catalyst loading and initial $\mathrm{pH}$ were also studied, which indicated the photodegradationwas suitable at low $\mathrm{pH}$ value. And optimal $\mathrm{TiO}_{2}$ loading was $80 \mathrm{mg} / \mathrm{L}$.

\section{ACKNOWDGEMENT}

Financial support of Nanjing University of Science and Technology is kindly acknowledged.

\section{REFERENCES}

[1] R. Lebrero, L. Bouchy, R. Stuetz, et al., "Odor Assessment and Management in Wastewater Treatment Plants: A Review," Crit. Rev. Environ. Sci. Technol., Vol.41, pp. 915-950, 2011.

[2] J.A. Nicell, "Assessment and regulation of odour impacts," Atmospheric Environment, Vol.43, pp. 196-206, 2009.

[3] A. Peter, O. Koester, A. Schildknecht, et al., "Occurrence of dissolved and particle-bound taste and odor compounds in Swiss lake waters," Water Res., Vol.43, pp. 2191-2200, 2009.

[4] D. Khiari and A. Bruchet, "The drinking water taste and odor wheel for the millennium: beyond geosmin and 2-methylisoborneol," Water Science and Technology, Vol.40, pp. 1-13, 1999.

[5] I. Suffet, D. Khiari and J. Mallevialle, Taste and odor problems in drinking water, in: Food Taints and Off-Flavours, Springer, 1996, pp. 107-138.

[6] T.-F. Lin, J.-Y. Wong and H.-P. Kao, "Correlation of musty odor and 2-MIB in two drinking water treatment plants in South Taiwan," Sci. Total Environ., Vol.289, pp. 225-235, 2002.

[7] Y. Yang, H. Zhong and C. Tian, "Photocatalytic mechanisms of modified titania under visible light," Research on Chemical Intermediates, Vol.37, pp. 91-102, 2011.

[8] A. Amtout and R. Leonelli, "Optical properties of rutile near its fundamental band gap," Physical Review B, Vol.51, pp. 6842-6851, 1995.

[9] C. Su, C.M. Tseng, L.F. Chen, et al., "Sol-hydrothermal preparation and photocatalysis of titanium dioxide," Thin Solid Films, Vol.498, pp. 259-265, 2006.

[10] Y. Wang, Y. Huang, W. Ho, et al., "Biomolecule-controlled hydrothermal synthesis of C-N-S-tridoped $\mathrm{TiO}_{2}$ nanocrystalline photocatalysts for NO removal under simulated solar light irradiation," J. Hazard. Mater., Vol.169, pp. 77-87, 2009.

[11] M. Pelaez, N.T. Nolan, S.C. Pillai, et al., "A review on the visible light active titanium dioxide photocatalysts for environmental applications," Applied Catalysis B: Environmental, Vol.125, pp. 331-349, 2012.

[12] C.C. Wong and W. Chu, "The direct photolysis and photocatalytic degradation of alachlor at different $\mathrm{TiO}_{2}$ and UV sources," Chemosphere, Vol.50, pp. 981-987, 2003.

[13] K. Mehrotra, G.S. Yablonsky and A.K. Ray, "Kinetic Studies of Photocatalytic Degradation in a $\mathrm{TiO}_{2}$ Slurry System: Distinguishing Working Regimes and Determining Rate 
Dependences," Ind. Eng. Chem. Res., Vol.42, pp. 2273-2281, 2003.

[14] K. Tanaka, K. Padermpole and T. Hisanaga, "Photocatalytic degradation of commercial azo dyes," Water Res., Vol.34, pp. 327-333, 2000.

[15] U. Stafford, K.A. Gray and P.V. Kamat, "Photocatalytic degradation of 4-chlorophenol: The effects of varying $\mathrm{TiO} 2$ concentration and light wavelength," Journal of Catalysis, Vol.167, pp. 25-32, 1997.

[16] D.W. Chen and A.K. Ray, "Photodegradation kinetics of 4-nitrophenol in $\mathrm{TiO} 2$ suspension," Water Res., Vol.32, pp. 3223-3234, 1998.

[17] A. Mills, R.H. Davies and D. Worsley, "Water purification by semiconductor photocatalysis," Chem. Soc. Rev., Vol.22, pp. 417-425, 1993.

[18] M. Muruganandham and M. Swaminathan, "Photocatalytic decolourisation and degradation of Reactive Orange 4 by $\mathrm{TiO}_{2}$-UV process," Dyes and Pigments, Vol.68, pp. 133-142, 2006. 